\title{
FINANCIAL ASPECTS ON LANDFILL MINING SEEN AS A PART OF THE URBAN MINING
}

\author{
William Hogland ${ }^{l}$ \\ Marika Hogland ${ }^{l}$ \\ Marcia Marques ${ }^{1,2}$ \\ ${ }^{1}$ Linnaeus University-LNU, Sweden \\ ${ }^{2}$ Rio de Janeiro State University-UERJ, Brazil
}

\begin{abstract}
Urban areas have deposits with large amounts of valuable materials that in future will be worth to mine, in particular when the natural resources will be scarcer. Landfill mining can be seen as a part of the urban mining, in particular when an old dumpsite suddenly is found in the middle of a new town district as the city expands. Landfill mining can be considered in the context of integrated solid waste management economics. A new concept of Enhanced Landfill Mining (ELFM) is used, which targets the integrated valorization of materials and energy from past, present and future landfills, while meeting the most stringent ecological and social criteria. In landfill mining, financial and environmental aspects, as well as the commercial aspects of land recovery and extraction of excavated resources are seen as part of the entire solid waste management. Practicalities with selection of sufficient and effective machinery, excavation, choosing proper logistics, storage and management of large masses of waste, handling of hazardous waste and health and safety in the working environment and for the public are also of high importance for the economy of a project. Traditionally, it is believed that the recyclables recovered might provide some economic revenue; the value depends on the amount and the quality of the separated fractions, local conditions and market prices. Ferrous metals, aluminum, plastic and glass as well as fine organic and inorganic material might be of economic interest when excavating today, but in the future, other metals and compounds may be recovered as micronutrients and micro-compounds. The accounting for economic benefits of a landfill-mining project must be fair and must include the economics of reduction or elimination of the need for capping, long-term monitoring and aftercare, maintenance and potential remediation costs, effective use and logistics of the machinery, future value of the reclaimed land and avoidance of sitting and infrastructure costs if the reclaimed land is used for construction of a new landfill.
\end{abstract}

\section{KEYWORDS}

Urban mining, landfill mining, recycling, emissions, EU-directive, economics

\section{INTRODUCTION}

Urban mining is usually defined as the process of digging the value out of dead technologies as for instant electronic scrap and in older days it goes back to different type of scavenger activities. Today more than half of the world population is today living in urban areas and 
they need a large amount of material and natural resource for their survival and living which to big extent is bound to buildings and the infrastructure, equipment and facilities. In a broader perspective cities can be seen as "dumps" or "material bank/deposit" consisting of materials of all kind buried as cables; wooden and metal poles; plastic, concrete and iron casted pipes; metal and plastic tanks and containers; etc that all contain a residual value in the form of material value. The hazardous waste and toxic chemical can on the other appear as cost for remediation and disposal. In this broader perspective landfill mining can be seen as part of the urban mining where the former city dump/landfill suddenly appears in the middle of the city as the urbanization expand and then makes hinder for the urban development or a hazard for the urban environment and human health. Dumpsite reclamation or landfill mining is the process of excavating from operating or closed solid waste landfills, and sorting the unearthed materials for recycling, processing, or for other dispositions ${ }^{1}$. From material recovery point view far from all dumpsites/landfill can be seen as treasury. However, the recyclables recovered might provide some economic revenue for a project but their value depends on the amount and the quality of the separated fractions, the local situation and market prices. Industrial landfills might contain valuable materials, for example those that have been operated by the car fragmentation and scrap electronics industries. In the scrape from electronics can include gold, silver, tantalum, tin, wolfram etc. From the economic point of view, landfill mining must be considered in the context of integrated solid-waste management economics and dealing with the waste fraction of the waste in new landfill, which in Europe means after sorting out recoverable and organic waste and environmental economics must be included. The economics of landfill reclamation are often considered to depend on the depth of the waste material and the ratio of soil to waste, because the deeper the waste is buried, the more expensive per hectare it is to reclaim a site. A new way of make landfill mining a economical option in urban area is Enhanced Landfill Mining (ELFM) which targets into integrated valorization of materials and energy from past, present and future landfills, while meeting the most stringent ecological and social criteria. ELFM has by Tom Jones at Centre for High Temperature Processes, Pyrometallurgy and Refractory Materials in Belgium been defined as following: ELFM targets integrated valorization of materials and energy from past, present and future landfills, while meeting the most stringent ecological and social criteria. Present paper presents urban mining in the landfill mining perspective and related economics.

\section{HUMAN NEEDS AND WANTS}

\section{Clean Air, Water and Land}

According to Maslow's hierarchy of needs, on the biological and physiological level people first of all require clean air to breathe, clean water to drink, clean and healthy food to eat and shelter. Landfilling is a threat to all these basic needs. For instance, they pollute the air with methane and $\mathrm{CO}_{2}$ and other gases depending on the chemical and biological activities of material in the landfill. Leachate and storm water from the landfill contaminate ground and surface waters, transporting the pollutants into the food chain. Waste dumping can also affect the shelter of people living near the landfill: for instance, avalanches and waste sliding can occur during rainy periods if the waste is not properly compacted and the primitive houses of usually poor people are easily buried in the waste mass. Fires, gas emissions and odors are also common in landfill areas and can affect the local area around the landfill and even make evacuation necessary. In some ways, landfill can make clear footprints for air, water and land but in many cases, the footprints are diffuse in the long term and global or regional perspective. All this create costs for society of different kind. 
Emissions to air that act on the global level include methane and $\mathrm{CO}_{2}$. The total bill for global warming has not yet arrived, but it is possible to transfer the damage or the economic value of the landfill emission by using $\mathrm{CO}_{2}$ credits and also to transfer it for financial support of landfill-mining projects and land reclamation. Economic compensation for disturbances of the neighborhood by odors and vectors from a landfill might be limited to one-time or an annual compensation to each household of some few thousand euros or more. For continuous emissions from pyrolysis or deep fires causing gas and smoke pollution into the air, no compensation is given in many parts of the world. At many landfills and dumpsites, even deliberately lit fires occur frequently and affect the air quality mainly on the local and regional level. It is really hard to interpret these "accidents" in monetary terms or to assign liability for payment. To be prepared for these occasions, the waste management companies in industrial countries have invested in fire protection equipment and courses of training for personnel. During a fire, the waste management company must pay extra salaries and cover extra operation costs. The aftercare, handling and final disposal of the remaining burned waste and ashes must be handled properly, which can be costly. The fire brigade costs are usually covered by society through tax money and so are any required evacuations. The insurance company covers some of the costs and each public citizen may take some private costs for transport or medical consultancy that are not covered from anywhere else.

Pollution of water resources and rivers or seas by leachate and storm water from the landfill area might be costly to treat in the long run, for drinking, industrial or recreational use. Each cubic meter of clean groundwater that can no longer be used for drinking purposes gives a minimum cost as loss of commercial value of about 1 euro per cubic meter and a treatment cost of 2 to 20 euro per cubic meter or more. Leachate is commonly transferred to an ordinary municipal wastewater treatment plant and the cost for the handling can be set as for ordinary wastewater.

The world-renowned concept "virtual water", introduced by the award winner of 2008 Stockholm Water Prize Laureate Professor John Anthony Allan from King's College of the University of London, measures the volume of freshwater required in the production and trade of agricultural and industrial products. The largest consumption of water occurs during food production and a balance of global marketing is required to even up the distribution of water supply over the world. The import of water-intensive commercial goods and water-effective production of crops as well as reducing the spill of pollution in fresh water could solve problems for countries with scarcity of water. This is especially important in environmentally sensitive areas, where the location of landfills is based more on convenience than on hydro geological aspects.

Soil pollution and pollution of land by landfilling and dumping decrease land values. Reclamation increases land values and the recovered land can be used for shopping centers or industrial sites, or hotel areas. It can increase aesthetic values; recover commodities and land; enhance the land's value and help to achieve country/EU recycling and environmental goals as well complying with for instance the EU landfill directive.

\section{LEGISLATION AND REGULATIONS}

The Resource Conservation and Recovery Act in the USA has forced many landfills to close during the last two decades ${ }^{2}$. Similar effects have occurred in Europe in response to the EC Landfill Directive (1999/31/EC) mentioned earlier, which requires that landfills have a bottom liner and that also states that the landfilling of organic waste must be phased out. This means waste minimization and pretreatment before landfilling is encouraged; this will result 
in poorer landfill in the future, and the interest in material recovery might be lower. Directive 2008/98/EC of $19^{\text {th }}$ November 2008 has forced many landfills to close down during the last decade, due to it requires that landfills have a bottom liner and that also states that the landfilling of organic waste must be phased out. The landfill mining is not so clear regulated in the Directive and it has been noted in the Directive 2008/98/EG that recycling of waste need to assess the existing definitions of recovery and disposal, the need for a generally applicable definition of recycling and a debate on the definition of waste. After the landfill has been definitively closed, the owner-operator shall be responsible for its maintenance, monitoring and control procedures for 30 years, according to the directive, or longer if required by the competent authority. The costs are dependent on the expenditure and duration of the aftercare measures necessary. The Council confirmed that waste prevention should be the first priority of waste management, and that re-use and material recycling should be preferred to energy recovery from waste, where and insofar as they are the best ecological options. In the landfill mining concept it must first be decided if the recycling of material is a realistic option compared to the energy utilization alternative.

\section{MATERIAL RECOVERY}

Cost and benefits for reclamation projects will vary considerably depending firstly on the goal of the site owner-operator: reduction of the landfill area and cap; recovery of airspace for continued operation; upgrading or installing a liner; or removal of the landfill entirely or a combination of these. Secondly, site-specific physical conditions play an important role in determining whether the landfill operator's goals can be achieved. These conditions include the soil-to-waste ratio, depth of the waste, type of waste and the presence of standing water, as well costs for disposing of waste off-site if that should be required.

Landfills in Sweden from the 1960s, for example, have quantities of construction and demolition waste materials, reflecting that era's construction boom. According to the US Environmental Protection Agency, more than 130 million tonnes of construction and demolition debris (C\&D) become waste in landfills each year. Other landfills include highly specific waste, such as that from vehicle fragmentation companies. Increased environmental awareness and eco-trends have favored markets for recyclable and reusable material. Presumably the biggest reason is the increase in the price of petroleum, which puts a new focus on metal and plastic in landfills. For instance, Asian countries make high bids for imported plastic and scrap metal for their industries although, since the 1980s, their landfills hold large amounts of waste from industrialized countries ${ }^{3}$.

The demand for valuable metals such as aluminum, copper and iron on the global market is contributing to recycling by scrap dealers. They are happy to maximize profits if the local EPA does not impose demands on them to reduce the risk of environmental impact. Paper, wood, stones, bricks, plastics and other materials are also recoverable from landfills. More than $20 \%$ plastic in landfills has been reported in some developing countries ${ }^{4)}$. Furthermore, about 5\% more energy is required to produce aluminum from the ore than to recycle it According to an estimation performed by USEPA, in the year 2006 recycling of 82 million tons of Municipal Solid Waste (MSW) saved the energy corresponding to more than 40 billion liters of gasoline and each ton of recycled paper saved energy corresponding to 700 liters of gas. 


\section{SOIL-TO-WASTE RATIO}

Soil excavation is an expensive part of the procedures in landfill mining. General experience shows that the average soil fraction in recovered municipal waste from landfills tends to be around $50-60 \%$. However, Hogland ${ }^{5)}$ showed that it could vary between 20 and $80 \%$ in studies from 15 excavated landfills in four countries on two continents. Furthermore, the soil fraction depends on moisture content and decomposition rate as well as the age of the landfill. Except where the soil fraction can be used as cover material or as soil amendment, there must be other incentives for excavation. If the soil fraction has good quality and compost standard could be guaranteed, the soil can give an income of 10 euro per ton or more. When it is used for cover material, the income is related to the local prices; these can increase considerably if there is a lack of alternatives. In particular, the fine fraction $(<18 \mathrm{~mm})$ can be used as compost for soil amendment, or daily or final cover of landfills. Polluted soils can in some cases be upgraded by instant bioremediation to useful soil.

If the degradation of the deposited material is speeded up, it may be possible to recover materials after closure and give the landfill site an opportunity to have free space for more landfilling and be accepted to receive new types of waste that might be a segregated fraction. Of course, the new landfill must fulfill the new landfill standards and be equipped with control systems and constructed with liners.

\section{ENERGY FROM WASTE}

The coarse fraction ( $>50 \mathrm{~mm}$ ) of the recovered organic masses can be incinerated directly, and sometimes the medium $(18-50 \mathrm{~mm})$ fraction can be incinerated with additional fuel. The fine fraction $(<18 \mathrm{~mm})$ cannot be incinerated because of its low calorific value and very high ash content. Cossu et al. ${ }^{6}$ ) found the energy value of excavated waste in Italy varied between 3.4 and $8.7 \mathrm{MJ} / \mathrm{kg}$ with a mean value of $4.5 \mathrm{MJ} / \mathrm{kg}$ ). Hogland et al. ${ }^{7)}$ and Hogland ${ }^{5)}$ found during an excavation in Sweden that the energy value varied between 6.9 and $7.9 \mathrm{MJ} / \mathrm{kg}$ in the light fraction and less than $2 \mathrm{MJ} / \mathrm{kg}$ in the fine fraction. Obermeier and Saure ${ }^{8)}$ obtained a value of $11 \mathrm{MJ} / \mathrm{kg}$; Cossu et al. ${ }^{6)}$, Rettenberger et al. ${ }^{9)}$ and Schillinger et al. ${ }^{10)}$ found values up to 20 $\mathrm{MJ} / \mathrm{kg}$ in an unsorted light fraction. ( $84 \mathrm{TJ}=2000$ ton of oil or 13500 barrels of oil to a value of about euro 140 per barrel in monetary values of 2008).

Removing cover material from the waste before excavation produces a cleaner and more efficient fuel. Forster ${ }^{11)}$ reports in a study during 1992-93 in the USA that 56\% of the total excavated tonnage was converted into fuel and $41 \%$ of the excavated mass was recovered as soil during trommeling operations; the remaining 3\% was noncombustible materials that were landfilled again.

Composting has been suggested by Collins et al. ${ }^{12)}$ to dry the excavated waste before thermal processing. This will improve the screening efficiency for the removal of the fines, as well as remove adhering solids and therefore reduce ash generation during thermal processing. However, each such activity increases the cost and a cost-benefit analysis must be done for each such processing step introduced.

The additional waste mass from the mining can be used to maximize boiler efficiency and by that increase the power production and the electricity and heat distribution revenues. When used as fuel, the ash residue should be tested regularly for total and toxicity characteristics: leaching metals, moisture content, $\mathrm{pH}$, percentages of carbon and chlorides. 
Landfill gas can be produced if the medium fraction of the excavated waste is moistened and landfilled again in a cell; the landfill gas can be vacuumed off and the waste taken to a gas plant. It can be advantageous to moisten with recycled leachate for rapid biological stabilization. The leachate recycles any toxicity through repeated contact with the microorganisms in the new landfill cell. Hogland ${ }^{13)}$ studied backfilling of the $18-50 \mathrm{~mm}$ fraction of excavated material into a cell and moistening with leachate. The production of methane began immediately in the cell and the methane content was about 50-57\% during the first 1.5 years. Therefore, the middle fraction can be backfilled and the methane vacuumed off or the material taken to a biodigestion plant. The maximum potential of gas extraction from the waste is about $200-300 \mathrm{~m}^{3}$ per ton waste and the value of the gas is about $1.25 \mathrm{euro} / \mathrm{m}^{3}$.

\section{EXTENSIONS OF LIFETIME OF LANDFILL, REDUCTION OF CLOSURE COSTS AND AFTERCARE}

An extension of many years of the lifetime of existing landfills is an important goal, which avoids the cost and time required to locate, design, permit and construct new landfills or implement alternative waste-management systems. The infrastructure, waste management facilities and approach roads can be used for another 5-10 years before new virgin land must be taken to erect a new modern sanitary landfill according to existing directives.

The easiest way to secure financial support for a mining project is if the land is wanted for other purposes, or if it can reduce the closure costs for the landfill, or if leachate treatment costs can be avoided during the next 30 years and future environmental problems such as pollution of existing drinking water sources nearby can be avoided. Leachate treatment cost can easily be 15-20 000 euros for a small landfill per annum. The amount of leachate produced at covered and closed old landfills has been assumed to be $2000 \mathrm{~m}^{3} /$ ha per year in Sweden ${ }^{14)}$.

Aftercare includes elimination of pollution through destruction, concentration or excavation of polluted material and also methods for encapsulation or immobilization to reduce the spread of the pollutants. Landfill mining reduces the costs of closure and aftercare which, according to Heyer et al. ${ }^{15)}$, include the following expenses of importance: temporary surface cover; final surface sealing; necessary enhancement of the base sealing system; collection and treatment of leachate; collection and treatment of landfill gas (benefits for utilization, costs for weak gas treatment); enhancement measurement for the emission potential; water infiltration and aerobic in situ stabilization (additional costs for investments and operation, cost savings in the aftercare); and dismantling of dispensable equipment and buildings. Other costs include monitoring for supervision of: settlements, leachate and groundwater; Landfill gas: weather and climate conditions; technical equipment; sealing; collection systems; and documentation and reports. Both investment and operating costs must be calculated.

The landfill owner-operator must provide sufficient funds to cover the whole landfill closure and the aftercare period or the land reclamation and material recovery. Many municipalities give financial support for these types of operations. According to Heyer et al. ${ }^{15}$ ) the specific costs for aftercare for German landfills are $7.5-24 \mathrm{euro} / \mathrm{m}^{3}$ with an average of 13 euro $/ \mathrm{m}^{3}$. The closure and aftercare measurement costs depend on the local boundary conditions and the existing technical systems and equipment: temporary surface covers: 5-25 euro/ $\mathrm{m}^{2}$ landfill surface depending on the required lifespan and design (e.g., options for final integration in the final surface sealing); final surface sealing: $35-87 \mathrm{euro} / \mathrm{m}^{2}$ landfill surface for material and application; collection and treatment of leachate: $15-50$ euro $/ \mathrm{m}^{3}$ leachate at 
landfills with a base sealing system; in situ stabilization such as infiltration or aeration: $0.5-3$ euro $/ \mathrm{m}^{3}$ of landfill volume. Even after the aftercare phase there might be minor activities such as leachate pumping, cleaning of drainage pipes, care of the vegetation, natural post treatment of leachate on site, control of sewage pipes, access holes and also groundwater monitoring. Liners and leachate and gas collection systems can easily be repaired or installed in the landfill during excavation activities.

\section{INCREASE OF LAND VALUE}

"Not in my back yard" is a common expression in public debates, even from those of us that have lived close to an old MSW landfill that has been transformed to a city park and has seen the market value of our flat or house increase 10-20 times during one or two decades. Such a city park can be constructed in different ways and gives possibilities for jogging, walking, bird watching, camping, biking, theatrical performances, skiing, flying kites and various other activities. The major benefit from the mining approach is commonly related to the recovery of land for use as for instance shopping centers, industrial areas, new town districts, or complicated road junctions. Recovery of commodities and land, enhanced land value and "footprints" of the former activity can be reached. During landfill reclamation projects, expenses as effects of natural cause parameters such as climate, soil condition, the volume and the topography of the landfill must be considered.

\section{DISCUSSION AND CONCLUSIONS}

Urban mining is here to stay and a lot of the earth resources are bound or deposited in urban areas in buildings, roads and constructions related to the infrastructure and equipments and tools for daily use to make life easier for men. In the mining for natural material resources and oil we need to dig or drill deeper which makes that type of mining or utilization of the natural resources more and more expensive. There is a need of mapping of where and how much of existing material and energy resources that are bound to different urban constructions and equipment/tools in the society. In the future we need to make data bases over were the materials are used and to what amount they are bound to different constructions/ equipment/machines. It must also be control over the hazardous waste and chemicals in the society, if hazardous/semi hazardous material have been used in for instant road constructions or in concrete in building construction. Such a data base should be a valuable tool in the urban mining and make the planning of the recovery of the materials and the energy utilization easier, environmentally friendly and more economic. There is also a need for economic models for calculations giving economic incitements for urban mining and separation of material and energy utilization. In order to make landfill mining profitable it must be included in the integrated solid waste management and include all environmental benefits in monetary terms and all other economic profits of the project and not just the value of the most interesting materials dumped $\left.{ }^{16)}, 17\right), 18$ ).

\section{REFERENCES}

1)(Salerni, 1995); Salerni, E. L., 1995. Landfill Reclamation Manual. Reclaim '95 Landfill Mining Conference, 28-29 September, 1995, SWANA Landfill Reclamation Task Group, USA. p. 16. Schillinger et al. 1994. Summary of Landfill Reclamation Feasibility Studies. NYSERDA. 
2) (Goldstein and Madtes, 200); Goldstein, N. and Madtes, C. 2001. The State of Garbage in America. BioCycle, 42 (12). p. 42-54.

3)(Joseph et al., 2008); Joseph, K., Nasgendran, R., Thanasekaran, K., Visvanathan, C., Hogland, W., Kathikeyan, O., P. and Moorthy, N. 2008. Dumpsite Rehabilitation Manual, Centre for Environmental Studies, Ann University, Chennai - 600 025, India. p. 140. Morris, J. 1996. Does Recycling Pay? Http://wasteage.com/mag/ waste recycling pay/ indes1.html, Date. 2009.03.03.

4)(Carius et al., 1999); Carius, S., Hogland, W., Jilkén, L., Mathiasson, L. and Andersson, P-Å. 1999. A Hidden Waste Material Resource: Disposed Thermoplastic. In: Proc. Sardinia'99, the $7^{\text {th }}$ International Waste Management and Landfill Symposium, 4-8 October, 1999, Cagliari, Italy. pp. 229-235.

${ }^{5)}($ Hogland 2002); Hogland, W. 2002. Remediation of an Old Landfill Site - Soil Analysis, Leachate Quality and Gas Production. ESPR - Environ Sci \& Pollut Res. Special Issue 1. pp. 49-54.

${ }^{6)}$ (Cossu et al. (1995); Cossu, R., Motzo, G. M. and Laudadio, M. 1995. Preliminary Study for a Landfill Mining Project in Sardinia. In: Proc. Sardinia'95, The $5^{\text {th }}$ International Landfill Symposium, Cagliari, v. III. pp. 841-850. EU Directive on Landfill of Waste. European Union Council Directive 1999/31/EC issued 26 April 1999.

${ }^{7)}$ Hogland et al. (1995); Hogland, K.H.W., Jagodzinski, K. and Meijer, J.E. 1995. Landfill Mining Tests in Sweden. In: Procs. Sardinia'95, The $5^{\text {th }}$ International Landfill Symposium, $2-$ 6 October, 1995, Cagliari, Italy.

${ }^{8)}$ (Obermeier and Saure 1995); Obermeier, T. and Saure, T. 1995. Landfill reconstruction, biological treatment of landfill waste Proceedings, Sardinia'95, The $5^{\text {th }}$ International Landfill Symposium, Christensen et al., ed., Cagliari, v. III. pp. 819-826.

9), (Rettenberger et al.1995); Rettenberger, G., Urban, K., Schneider, R. and Göschl, R. German Project Reconverts a Sanitary Landfill. Biocycle, June, 1995. pp. 44-48.

${ }^{10)}$ Schillinger et al. (1994); Salerni, E. L., 1995. Landfill Reclamation Manual. Reclaim '95 Landfill Mining Conference, 28-29 September, 1995, SWANA Landfill Reclamation Task Group, USA. p. 16. Schillinger et al. 1994. Summary of Landfill Reclamation Feasibility Studies. NYSERDA.

${ }^{11)}$ Forster (2001); Forster, G.A. 2001. Assessment of Landfill Reclamation and the Effects of Age on the Combustion of Recovered MSW. Feature Article March/April 2001, MSW Management, Forester Communication Inc. Canada. pp. 11.

${ }^{12)}$ Collins et al. (2001); Collins, H. J., Brammer, F. and Harms-Krekeler, C. 2001. Rückbau von Sidelungsabfall. Müll-Handbuch (Hösel, G., Bilitewski, B., Schenkel W. and Shanurer, H. eds.), Kennzahl 4670, Lieferung 3/01, Erich Schmidt, Berlin, Germany. 
${ }^{13)}$ Hogland (2001); Hogland, W. 2001. Landfill Mining and Remediation of Soils. In: Book of Abstracts, Workshop on Management of Industrial Toxic Wastes and Substances Research Bioremediation and Polluted Ecosystems, the $2^{\text {nd }}$ CCMS/NATO Workshop, Instituto Le Monacelle, Matera, Italy, 20 December, 2001.

${ }^{14)}$ Hogland and Nimmermark, 1998); Hogland, W and Nimmermark, S. 1998. Assessment of Waste Masses in Old Landfills in Sweden. In: Proc. of the $2^{\text {nd }}$ International Youth Environmental Forum ECOBALTICA’98, 22-26 June, 1998, St. Petersburg, Russia.

${ }^{15)}$ Heyer K-U., Hupe. K. and Stegmann R. (2005) Landfill Aftercare - Scope for actions, duration, costs and quantitative criteria for the completion. Proceedings of Sardinia 2005, 10th International Waste Management and Landfill Symposium, S. Margherita di Pula, Cagliari, Italy, 3-7 October 2005, p. 11

16)(Stenis, 200); Stenis, J. 2005. Industrial management models with emphasis on construction waste. Doctoral thesis. Department of Construction and Architecture, Lund Institute of Technology, Lund University, Lund.

17)(Moutavtchi et al 2008); Moutavtchi, M., Stenis, J., Hogland, W., Shepeleva, A. and Andersson, H. 2008. Application of the WAMED model to landfilling. J Mater Cycles Waste Manag 10:62-70.

18)(Hogland and Stenis, 2008); Hogland, W. and Stenis, J. 2008. The Economics of Waste Management: Applying the Equality Principle. In "WASTEnomics: Turning waste liabilities into assets”, Yeoh, J. and Tang, K., (eds), Middlesex University Press, ISBN 9781904750 28 4. pp. 33-40. 